УДК 159.922.63

\title{
КОГНІТИВНИЙ ПІДХІД ДО ЗБІЛЬШЕННЯ ПІЗНАВАЛЬНИХ РЕСУРСІВ ТА ПОКРАЩЕННЯ РОЗУМОВОЇ ДІЯЛЬНОСТІ ЛІТНЬОЇ ЛЮДИНИ
}

О. В. Тополь, д. фрілос. н., профрecop

Актуальність теми дослідження. В умовах збільшення тривалості людського життя, постаріння населення всього світу, актуальним $\epsilon$ дослідження особливостей розумової діяльності людини літнього віку, з метою їі покращення.

Постановка проблеми. 3 віком збільшується ризик небезпечних захворювань мозку різними формами старечої деменції. Навчитись відновлювати роботу мозкових клітин, перепрограмовувати мозок, запобігаючи процесам швидкого старіння $\epsilon$ надзвичайно важливим.

Аналіз останніх досліджень і публікацій. Важливими постулатами для досліджень когнітивних особливостей літньої людини стали твердження З. Фрейда, К. Юнга, А. Адлера.

Виділення недосліджених частин загальної проблеми. Ідеї З. Фрейда, К. Юнга, А. Адлера недостатньо використовуються у науковій геронтології.

Постановка завдання. Метою даної статті є розкриття сутності когнітивного підходу в питання розвитку особистості літньої людини, збільшення пізнавальних ресурсів та покращення їі розумової діяльності.

Виклад основного матеріалу. При діагностиці когнітивних процесів проявляються рівні інтелекту "рідкого (fluid)» (вроджені задатки та здібності) та «кристалізованого (crystallized)» (набуті знання, уміння й навички когнітивної діяльності). Останній, при постійній розумовій діяльності у літньому віці не лише не погіршується, а і підвищується, характеризується достатнім рівнем загальної освіченості, поінфрормованості, спирається на досвід і тісно пов'язаний з мудрістю.

Висновки. Когнітивно-біхевіористські підходи доцільно використовувати в 8 терапевтичних цілях лікування когнітивних розладів у літніх людей (усунення/зменьшення симптомів хвороби мозку, попередження рецидивів, поліпшення ефректу медикаментозного лікування), а також розвитку і покращення когнітивних можливостей. Останнє вимагає зміни психологічних установок, думок, ставлення до життя, формування позитивних поведінкових патернів.

Ключові слова: когнітивний підхід; когнітивні процеси; літній вік.

O. V. Topol, Doctor of Philosophy, Professor

\section{COGNITIVE APPROACH TO INCREASING COGNITIVE RESOURCES AND IMPROVING THE MENTAL ACTIVITY OF THE ELDERLY}

Urgency of the research. In terms of increasing the duration of human life and the aging of the population around the world, it is relevant to study the features of the mental activity of the elderly in order to improve it.

Target setting. With age, the risk of dangerous brain diseases with various forms of senile dementia increases. Learning to restore brain cells, reprogram the brain, preventing rapid aging is extremely important.

Actual scientific researches and issues analysis. Important postulates for the study of cognitive features of the elderly were the statements of S. Freud, K. Jung, A. Adler.

Uninvestigated parts of general matters defining. Ideas of S. Freud, K. Jung, A. Adler not enough used in scientific gerontology.

The research objective. The purpose of this article is to reveal the essence of the cognitive approach to the development of the personality of elderly, increase cognitive resources, and improve their mental activity. 
The statement of basic materials. When diagnosing cognitive processes, the levels of intelligence "fluid" (innate inclinations and abilities) and "crystallized" (acquired knowledge, skills, and abilities of cognitive activity) appear. with constant mental activity in old age the last one does not deteriorate, but on the contrary increases, is characterized by a sufficient level of general education, awareness, relies on experience, and is closely related to wisdom.

Conclusions. Cognitive-behavioral approaches should be used for therapeutic purposes in the treatment of cognitive disorders among the elderly (elimination/reduction of symptoms of brain disease, prevention of relapses, improving the effectiveness of drug treatment), as well as the development and improvement of cognitive abilities. The latter requires a change in psychological attitudes, thoughts, attitudes to life, the formation of positive behavioral patterns.

Keywords: cognitive approach; cognitive processes; old age.

DOI: 10.25140/2412-1185-2019-2(14)-77-83

Актуальність теми дослідження. В умовах збільшення тривалості людського життя, постаріння населення всього світу, актуальним $€$ дослідження особливостей розумової діяльності людини літнього віку, з метою ії покращення. Наукові течії, базуючись на різноманітних методологічних основах проведення дослідження, по-різному трактують процеси старіння та його вплив на особистість людини. Наукові течії, що спираються на біологічну парадигму, імпліцитно розуміють лінійну траєкторію людського життя: активний розвиток у дитинстві та молодості, досягнення плато у дорослості, потім неминучі погіршення та ослаблення фрункціонування організму та всіх процесів по мірі наближення до старості. Такий погляд на процеси старіння, як руйнівні для організму, по-перше, провокують розмисли про деградацію всіх функцій організму з віком; по-друге, формують відразу та негативізм до старих людей. Когнітивний підхід у дослідженні процесів старіння, $€$ більш прогресивним та оптимістичним поглядом.

Постановка проблеми. 3 віком збільшується ризик небезпечних захворювань мозку різними формами старечої деменції. Хвороби Альцгеймера, Паркінсона, Піка, Корсакова вважаються старечими захворюваннями, викликаними ушкодженням мозкових клітин. Проте одні літні люди демонструють приклади надзвичайного розквіту творчої діяльності та наукової активності, зберігають гострий розум і високу когнітивну працездатність до глибокої старості, а інші, швидко розумово деградують. Навчитись відновлювати роботу мозкових клітин, перепрограмовувати мозок, запобігаючи процесам швидкого старіння $є$ надзвичайно важливим.

Аналіз останніх досліджень і публікацій. Всі сучасні психологічні теорії старіння так чи інакше виходять з трьох базисних: психоаналізу 3. Фройда (Freud, S.), психоаналітичної теорії К. Юнга (Jung, С.) та індивідуальної психології А. Адлера (Adler, А.).

Виходячи з теоретичних положень 3. Фройда, динаміка особистості визначається способами розподілення і використання психічної енергії, яка іде на задоволення біологічних, психологічних та соціальних потреб, оскільки кількість енергії обмежена. В молодому віці «ід» (біологічна складова особистості) володіє всією енергією і використовує ії для задоволення інстинктів. У літньому віці розподіл енергії стабілізується, менше ії вимагається для задоволення тілесних потреб. Зменшується не лише частина енергії, яка витрачалася на стримування імпульсивної енергії «ід», а також і енергії «суперего», що забезпечувала процес соціалізації, засвоєння суспільних норм. Важливим постулатом для подальших досліджень когнітивних особливостей літньої людини стало твердження Фройда про те, що частина енергії «его» використовується на те, щоб перевести на вищий рівень різні психічні процеси - сприйняття, мислення (судження, абстрагування, узагальнення і міркування), уяву.

К. Юнг розглядав людське життя як безперервний розвиток в якому особистість прагне до цілісності та завершеності. Під розвитком людини (досягнення самореалізації) К. Юнг розумів розкриття вродженої недиференційованої цілісності. Щоб особистість була здоровою, кожна система повинна мати можливість досягнути повної диференціації, розвитку і вираження (процес індивідуалізації) [1]. Коли завдяки процесу індивідуалізації досягнуте внутрішнє розмаїття особистості, за допомогою трансцендентної функції, диференційовані системи інтегруються з метою досягнення ідеальної мети досконалої цілісності (самості). За допомогою процесу індивідуалізації і трансцендентної функції відбувається перенесення психічної енергії 
(сублімація) з примітивних, недиференційованих, інстинктивних процесів до вищих культурних, релігійних, духовних, більш диференційованих. Прогресивному процесу сублімації, що рухає психіку вперед, протилежним $є$ регресивний процес витіснення енергії в несвідому сферу, що проявляється в ірраціональній та імпульсивній поведінці.

Несвідоме представлене у структурі особистості К. Юнга двома процесами - несвідомим особистим та колективним. «Воно» (несвідоме) містить можливості, приховані від свідомого розуму, бо розпоряджається підсвідомим змістом (тим, що витіснено з актуальної пам'яті або зафріксовано неусвідомлено), а також мудрістю і досвідом незлічимих століть, які осіли у його архетипічних органах. Колективне (трансперсональне) несвідоме К. Юнг вважає найбільш сильною і впливовою психічною системою, що в патологічних випадках перекриває «его» та особисте несвідоме. «Підсвідоме не лише сховище минулого, але й вмістище майбутніх психологічних явищ та ідей», - зазначає К. Юнг [2, с. 33].

Більшість положень індивідуальної психології А. Адлера (Adler, А.) виходили з розуміння цілісності індивідууму, поведінкові паттерни якого не можна розглядати в ізоляції, а тільки у взаємозв'язках розумового, тілесного та психічного життя. Розгляд людини як органічної цілісності, що вимагає єдиного психодинамічного підходу, А. Адлер вивів з принципу, що життя це безперервний рух у напрямку росту й розвитку, цілісність досягається тільки у прагненні особистості до досконалості.

Важливими рисами теорії особистості А. Адлера стали такі припущення: 1) люди в першу чергу соціальні, а не біологічні істоти, їхня поведінка визначена не вродженими, а соціальними мотивами; 2) «Его», «креативне Я» - високо персоналізована суб'єктивна система, яка інтерпретує і усвідомлює досвід організму, є провідною у структурі особистості, спонукальною силою її розвитку; 3) особистість унікальна, з притаманною їй системою мотивів, рис, інтересів, цінностей, кожна дія людини має відбиток властивого їй життєвого стилю.

А. Адлер у своїй теорії виходив із міркування, що поведінкові паттерни людини фрормують не лише внутрішні психічні процеси або зовнішні причини, а скоріше, особистісно значимі життєві цілі. Загальні цілі, визначені людиною, їхнє значення та засоби досягнення визначають вектор життєдіяльності людини. Оскільки, за А. Адлером, як цілі так і шляхи їхньої реалізації значною мірою індивідуальні, люди здатні не лише самовдосконалюватись, а і проектувати власне життя.

Реальним стимулом, мотивацією поведінки, за А. Адлером, є очікування, фінальна ціль, а не минулі переживання. Фінальною ціллю А. Адлер назвав «прагнення до переваги», під яким розуміється прагнення до самоактуалізації, «великий рух угору». Припускаємо, що старість $є$ важливим періодом розвитку, на якому реалізується прагнення до завершеності. Прагнення до переваги, досягнення досконалості у кожного виражається по різному. Одна людина намагається здобути перевагу розвиваючи інтелект, інша - вдосконалюючись фізично. Відповідно цілі - формується життєвий стиль людини. А. Адлер висунув ідею «креативної сили Я», згідно якої людина сама створює свою особистість і будує свою долю.

Виділення недосліджених раніше частин загальної проблеми. Ідеї Фрейда та Юнга про свідомі та несвідомі процеси психіки не знайшли достатнього висвітлення в геронтологічних знаннях. Ідеї Адлера про те, що людина здатна ставити цілі, фоомувати наміри, і таким чином змінювати власне життя, використовуються в багатьох езотеричних школах, проте в науковій геронтології, цьому мало приділяється уваги.

Постановка завдання. Метою даної статті $€$ розкриття сутності когнітивного підходу в питання розвитку особистості літньої людини, збільшення пізнавальних ресурсів та покращення ії розумової діяльності.

Виклад основного матеріалу. Когнітивна психологія вивчає пізнавальні психічні процеси (пам'ять, уяву, відчуття, сприйняття, мислення), увагу як умову протікання психічних процесів. За аналогією з роботою комп'ютера, когнітивна психологія досліджує всі процеси, які відбуваються у мозку в зв'язку з отриманням інформації, ії структуруванням, запам'ятовуванням, відтворенням та використанням.

Важливим в цьому контексті $€$ не лише діагностування рівня когнітивних здібностей, а і моделювання алгоритму протікання мозкових функцій та покращення їх функціонування.

Теоретична модель когнітивного розвитку особистості людини має такі стадії. Перша стадія набуття когнітивних умінь та навичок (acquisitive stage), найбільш активною $є$ у дитячому і підлітковому віці. Друга - стадія досягнення (stage of achievement) відповідає ранній дорослості 
та характеризується сприйнятливістю до засвоєння когнітивних навичок і умінням їхнього застосування у конкретній практичній ситуації. Середній вік проходить дві аналогічні стадії: стадію відповідальності (responsible stage), яка характеризується інтеграцією умінь розв'язувати складні соціальні проблеми та стадію ретельності (executive stage), на якій використовуються специфрічні стратегії, уміння і навички рішення комплексу проблем середнього віку. На заключній стадії реінтеграції (reintegration stage) раніше набуті інформація, досвід, стратегії рішення проблем реорганізуються на основі особистісно орієнтованих характеристик і ознак. Процес реінтеграції віддзеркалює унікальний вплив особистості на оточення, й навпаки, вплив оточення на особистість. Ця стадія найбільш характерна для літнього віку.

Ранні роботи з когнітивної психології сорормували розуміння різного роду когнітивних погіршень (відчутне зменшення когнітивних здібностей), пов'язаних із віковими змінами. Було виявлено, що 3 віком відбуваються втрати у таких видах когнітивної діяльності: здібності вирішення нових пізнавальних завдань; оперативній пам'яті, процесах кодування і переведення отриманого змісту у довгострокову пам'ять; швидкості запам'ятовування; опору перешкодам у процесі навчання; швидкості переробки інформації. Термін «когнітивне погіршення» часто використовується для позначення зменшення інтелектуальних здібностей у людей, які страждають від деменції та інших психічних захворювань.

Одним із перших досліджень когнітивних особливостей стало Сіетлське лонгитюдне вивчення старіння, яке провели К. Уорнер Шаи (Schaie, 1963) та його колеги [3]. Тестування інтелектуальних здібностей респондентів від 21 до 70 років, проводилось кожні 7 років. За результатами дослідження, інтелектуальний коефіцієнт респондентів відносно інших членів їхньої вікової групи, з віком майже не змінюється, хоча особистий результат погіршується. Було встановлено ряд змінних, які зменшують ризик когнітивного погіршення в старості: відсутність серцево-судинних та інших хронічних захворювань; проживання в сприятливих умовах оточуючого середовища, як це буває у осіб з високим соціально-економічним статусом, що мають вищу освіту, трудовий досвід високого рівня складності, прибуток вище середнього і сімейне благополуччя; виконання видів діяльності, які стимулюють інтелектуальну активність (читання, мандрівки, відвідування культурних заходів, продовження освіти, участь в клубах і професійних асоціаціях); шлюб із людиною, що має високий когнітивний статус; збереження в старості високих рівнів швидкості перцептивної обробки; задоволеність тим, як склалося життя [4].

Пізніше у наукових працях з когнітивної психології була відмічена одночасність прояву життєвої і професійної компетентності та підвищення уразливості організму в старості [5]. Профресійна і життєва компетентність людини підвищується, якщо вона протягом життя: заклала фундамент добре систематизованих, професійно-специфічних знань і фракторів того, як треба діяти; виробила ефективні стратегії рішення проблем, вивчення і запам'ятовування матеріалу, які дозволяють розв'язувати когнітивні завдання; оволоділа ефективними стратегіями роботи у професійній сфері і намагалася адаптуватися до нових професійних вимог; напрацювала способи вирішення завдань повсякденного життя, оволоділа уміннями розв'язувати конфлікти, переживати втрати (життєва компетентність); виховала в собі прагнення до новаторства, творчості, із зацікавленістю ставлячись до нових завдань розвитку і набуття нового досвіду.

Отже, когнітивний підхід враховує не лише особливості пізнавальних процесів, а також, персональні особливості літньої людини, що обумовлені особистісними, індивідуальними факторами (як людина сприймає і трактує власні вікові зміни, чи працює над собою з метою уповільнення процесів старіння та ін.), а також, соціальними (включеність індивіда у суспільне життя або його ізоляція).

Когнітивно-біхевіористичні теорії намагаються відповісти на питання «Які зміни особистості пов'язані з хронологічним віком у пізньому періоді життя?», беручи до уваги не лише зміни поведінки протягом життя, а і те, що залишається в особистості незмінним з роками, аналізуючи наскільки поведінка у пізній період життя пов'язана із поведінкою, притаманною попереднім періодам.

У результаті лонгитюдних досліджень був встановлений один із важливіших факторів, що характеризує інтелектуальне функціонування в похилому віці: помірний приріст багатьох інтелектуальних здібностей продовжується протягом періоду середнього зрілості, особливо розвивається вербальний інтелект та ті здібності, які постійно задіяні й використовуються в діяльності. Позиція дослідників когнітивно-біхевіористичного напрямку полягає в тому, що літня 
людина починає вибірково зосереджуватися на певних типах інтелектуальних занять, удосконалюючи певні уміння і розвиваючи здібності. Був введений термін «селективної оптимізації», яка відповідає за продовження пізнавальної діяльності у дорослому віці.

У контексті когнітивно-біхевіористської теорії старіння була запропонована когнітивна модель емоційних розладів А. Т. Бека [Beck, 1976]. Розумовий стан і поведінка індивіду детерміновані його переконаннями у ставленні до себе і до оточуючого світу. Система переконань індивіду може як стимулювати покращення пізнавальних здібностей, так і породжувати негативні думки, що викликатимуть труднощі у розв'язанні конкретних завдань. Наприклад, люди переконані, що їх самоцінність залежить від професійної діяльності, можуть відчувати страх перед наближенням пенсії [6].

При діагностиці когнітивних процесів проявляються рівні інтелекту які мають назви «рідкого (fluid)» та «кристалізованого (crystallized)» [7, с. 117]. Перший вид характеризується вродженими задатками та здібностями (коефіцієнт IQ, intelligence quotient). 3 віком показник цього виду інтелектуальної діяльності (швидкість отримання, обробки та використання інформації для розв'язання завдань) може знижуватись, оскільки літня людина за своїми психобіологічними особливостями здатна сприймати й утримувати меншу кількість сенсорних сигналів, а сповільнення протікання усіх процесів в організмі відбивається і на швидкості розумових дій. Таким чином, можуть фріксуватися погіршення у деяких когнітивних процесах, наприклад, погіршується короткочасна пам'ять.

Другий рівень інтелекту, «кристалізований», включає набуті знання, уміння й навички когнітивної діяльності, і проявляється здатністю до вирішення завдань шляхом логічних розумових дій та висновків. Він характеризується достатнім рівнем загальної освіченості, поінформованості, знаннями та досвідом розв'язання завдань, широким мовним арсеналом, розумінням подібності та відмінності явищ тощо. Такий рівень інтелекту при постійній розумовій діяльності не лише не погіршується, а і підвищується. Наприклад, літня людина в своїх спогадах зберігає всі деталі подій; змістовну інформацію, корисну і важливу для неї добре запам'ятовує.

Цей рівень інтелекту, як такий, що вимагає спирання на досвід, тісно пов'язаний з поняттям мудрості. Мудрість літньої людини проявляється в здатності розпізнання проблеми, з'ясування її причин та сутності а також активації вольових процесів для її усвідомлення, прийняття рішень та керування власними зусиллями щодо її розв'язання. Формування зважених, мудрих рішень відбувається не лише на когнітивному рівні, вони залежать від рівня особистісного розвитку в цілому (самооціночних якостей, вольової, емоційної, мотиваційної сфери, індивідуальнотипологічних особливостей). Розглядаючи мудрість як надбання літнього віку, слід розуміти її як підвищення моральності, глибини переживань, ускладнення психічної діяльності, духовних напрацювань.

Зниження рівня когнітивних процесів може бути наслідком захворювань мозку (неврологічні розлади, деменції, інсульт та ін.), загальних захворювань та побічних дій від зловживання алкоголю, ліків, не здорової їжі, а також психологічними розладами (знецінення себе, депресії, погані очікування) та соціальних умов (стреси, оточуюче середовище, місце проживання).

Старіння організму в цілому і когнітивні зміни, зокрема, не можна описати як лінійний процес росту, досягнення вершини та подальшого падіння. При погіршенні одних якостей, інші - можуть покращуватись.

Висновки. У літньому віці зменшується розмежування в роботі лівої та правої півкуль головного мозку, вони починають більш гармонічно взаємодіяти і мозок починає працювати активніше, ніж в молодості. Часто, саме з цієї причини, у людини похилого віку розкриваються творчі здібності.

Досвід розумової діяльності, який літня людина накопичила протягом життя, дозволяє їй знаходити варіанти вирішення тієї чи іншої проблеми найменш енергетично витратним шляхом i використовуючи менший за обсягом інформаційний та ресурсний матеріал. Розумові якості в літньому віці посилюються духовними, такими як любов, мудрість, готовність надати допомогу, здібність до співчуття.

Зниження когнітивних здібностей може бути наслідками патогенного мислення літньої людини, страху старості та смерті. Якщо негативні думки набувають ступеню фобій, вони перешкоджають нормальній роботі мозкових структур. 
Літня людина, розум якої відкритий до нових інтересів, нового пізнання, нових ідей, краси життя, буде відчувати себе молодою, життєрадісною, талановитою. Нові дослідницькі завдання, які ставить перед собою людина, дозволяють активізувати роботу мозку.

Зменшення потреби у концентрації уваги літньої людини на знаннях, пов'язаних із виконанням професійних обов'язків, дозволяє вивільнити час і ресурс для набуття знань в інших сорерах, які цікавлять людину. Інтерес та мотивація пізнання нового посилюють когнітивні здібності, пошукова інформація набуває векторності, а отримані знання більшої глибини. Гострий розум літньої людини відкриває незчисленні можливості для освоєння нових видів діяльності та реалізації творчих інтересів. Втілення творчих ідей, розвиток розуму, прагнення до пізнання, удосконалення душевних якостей - відкривають шлях до мудрого й гармонічного існування і керування власним життям.

Мисленнєва діяльність відбувається на двох рівнях - свідомому та несвідомому. У літньому віці, зменшується бар'єр між свідомістю та підсвідомістю, тим самим відкриваючи нові можливості для людського розуму.

Тому розумові здібності з віком можуть не лише не погіршуватись, а навіть покращуватись, виконуючи все більш різноманітну розумову діяльність.

Позитивні, глибокі емоції любові та радості сприяють більшому розкриттю талантів людини. Багато наукових відкриттів, фрілософських, літературних, художніх шедеврів створені саме талановитими людьми літнього віку. Що підтверджує те, що ментальні можливості людини невичерпні, а їх розвиток в будь якому віці, особливо в літньому, дає свої плоди. Бо похилий вік - це час активного пізнання та усвідомлення життя.

Когнітивно-біхевіористські підходи доцільно використовувати в терапевтичних цілях лікування когнітивних розладів у літніх людей (усунення/зменьшення симптомів хвороби мозку, попередження рецидивів, поліпшення ефекту медикаментозного лікування), а також розвитку і покращення когнітивних можливостей. Останнє вимагає зміни психологічних установок, думок, ставлення до життя, формування позитивних поведінкових патернів. Тут значну увагу слід приділити гармонізації діяльності несвідомої та свідомої мисленнєвої сфери літньої людини. За допомогою позитивних афірмацій слід перепрограмувати мозок людини на саногенне мислення. Саногенне мислення та поведінка здатні покращити когнітивну діяльність у літньому віці, в той час як патогенне - провокує когнітивні розлади.

\section{Література}

1. Юнг, К. Г. Структура психики и процесс индивидуации ; пер. с нем. / К. Г. Юнг ; Ин-т психол. РАН. - М. : Наука, 1996. - 269 с.

2. Юнг, К. Г. К вопросу о подсознании / Карл Густав Юнг ; пер. с англ. Н. А. Сиренко // Человек и его символы / К. Г. Юнг, М.-Л. Франц, Дж. Л. Хендерсон, и др. ; под общ. ред. С. Н. Сиренко. - М. : Серебрянные нити, 1998, - C. 13-102.

3. Schaie, K. W. The Seattle Longitudinal Study: A 21- year exploration of psychometric intelligence in adulthood. In K. W. Schaie (ed) Longitudinal Studies of Adult Psychological Development. New York: Guilford Press, 1983. - P. 64-135.

4. Шай, К. У. Интеллектуальное развитие у взрослых / К. У. Шай // Психологический журнал. - 1998. - Т.19. - № 6. - С. 72-89.

5. Хойфт, Гереон. Геронтопсихосоматика и возрастная психотерапия : учебное пособие для вузов / Г. Хойфрт, А. Крузе, Г. Радебольд. - М. : Академия, 2003. - 370 с.

6. Когнитивная терапия депрессии: научное издание / А. Т. Бек, А. Д. Раш, Б. Ф. Шо, Г. Эмери; пер. с англ. А. Татлыбаева. - СПб.: Питер, 2003. - 298 с.

7. Тополь, О. В. Освіта літніх людей: індивідуальний та суспільний запит / О. В. Тополь // Вісник НАУ. Серія: Філософрія. Культурологія. - 2015. - № 1 (21). - С. 116-119.

\section{References}

1. Jung, C. G. (1996). Struktura psikhiki $i$ protsess individuatsii [Structure and Dynamics of the Psyche]. Moscow: Nauka [in Russian].

2. Jung, C. G. (1998). K voprosu o podsoznanii [To the question of the subconscious] S. N. Sirenko (Eds.). Chelovek $i$ ego simvoly - Man and his symbols. (S. N. Sirenko, Trans). (pp. 13-102). Moscow: Serebriannye niti [in Russian].

3. Schaie, K. W. (1983). The Seattle Longitudinal Study: A 21- year exploration of psychometric intelligence in adulthood. K.W.Schaie (eds.). Longitudinal Studies of Adult Psychological Development. (pp. 64-135). New York: Guilford Press [in English].

4. Shay, K. U. (1998). Intellektualnoe razvitie u vzroslykh [Intellectual development in adults]. Psikhologicheskiy zhurnal - Psychological journal, 19(6), 72-89 [in Russian]. 
5. Heuft, G., Kruse, A., Radebold, H. (2003). Gerontopsikhosomatika $i$ vozrastnaya psikhoterapiya [Lehrbuch der Geronto-psychosomatik und Alterspsychotherapie]. Moscow: Akademiya [in Russian].

6. Beck, A. T, Rush, A. J., Shaw, B. F., \& Emery, G. (2003). Kognitivnaya terapiya depressii [Cognitive therapy of depression]. (A. Tatlybaeva, Trans). Saint Petersburg: Piter [in Russian].

7. Topol, O.V. (2015). Osvita litnikh liudei: indyvidualnyi ta suspilnyi zapyt [Education of elderly people: individual and social inquiry]. Visnyk NAU. Seriia: Filosofiia. Kulturolohiia - Visnyk of NAU. Series: Philosophy. Culturology, 1(21), 116-119 [in Russian].

Надійшла 23.11.2019

Бібліографрічний опис для цитування :

Тополь, О. В. Когнітивний підхід до збільшення пізнавальних ресурсів та покращення розумової діяльності літньої людини / О. В. Тополь // Проблеми соціальної роботи: філософія, психологія, соціологія. -2019 - № 2 (14) - С. 77-83. 